\title{
Spansk nivå III - nye læringsmuligheter og deltakelse i læringsrom i hverdag og fritid
}

\author{
Ane Christiansen \\ Charlottenlund Videregående skole
}

Berit Grønn

Høgskolen i Østfold

\begin{abstract}
Abstrakt
I en tid med økende globalisering og digitalisering møter dagens spanskelever målspråket i mange ulike situasjoner og i ulike læringsrom, noe som åpner for nye erfaringer med språk og språklæring. Denne artikkelen presenterer resultatene fra en kartleggingsunders $\varnothing$ kelse fra 2015 og en oppfølgende dybdeundersøkelse fra 2016 blant til sammen 205 elever som har valgt spansk på høyeste nivå i grunnopplæringa. Vi har unders $\varnothing k t$ hvilke læringsmuligheter elevene benytter seg av utenom skolen og hva slags betydning det spanske språket har i deres livskontekst. Vi fant at elevene i varierende, men utstrakt grad benytter seg av de $\varnothing$ kte læringsmulighetene, og at spansk oppleves som relevant i hverdag og fritid, men også med tanke på framtidig studie- og arbeidsliv. Resultatene viser at elevene er bevisste og deltakende aktører i ulike typer læringsrom og at de selv vurderer det som verdifullt å benytte seg av de $\emptyset \mathrm{kte}$ læringsmulighetene både faglig og personlig. Vi mener at en større bevissthet og kunnskap om de ulike læringsrommene elevene deltar i, vil kunne gi et mer helhetlig perspektiv på språklæringsprosessen deres og dermed være med på gjøre spanskfaget ytterligere relevant.
\end{abstract}

Nøkkelord: spansk, nivå III, videregående skole, programfag, fremmedspråksdidaktikk, læringsmuligheter, digitalisering, globalisering, læringsvilkår, læringsrom, livskontekst

\section{Innledning}

Digitalisering og større mobilitet på tvers av landegrenser og kontinenter resulterer i at spanskelever i den norske skolen har lettere tilgang til målspråket både i og utenom skolen nå enn før, noe som igjen gir økte læringsmuligheter: Det er lettere å komme i kontakt med autentisk språk, det være seg gjennom fysiske møter eller i virtuelle rom, men vi vet lite om i hvilken grad og hvordan elevene benytter seg av de $\varnothing$ kte læringsmulighetene. I denne artikkelen vil vi søke å finne noen svar på dette gjennom å presentere resultatene fra en kartleggingsunders $\varnothing$ kelse fra 2015 og en oppfølgende dybdeundersøkelse fra 2016 blant $\mathrm{i}$ alt 205 elever som hadde valgt spansk på høyeste nivå i studieforberedende utdanningsprogram i videregående opplæring, det vil si som programfag i fremmedspråk nivå III, jamfør Lareplan i fremmedspråk (Utdanningsdirektoratet 2006), heretter kalt laereplanen. Alle Spansk IIIelevene som var gjenstand for undersøkelsen var ordinære elever i vg3 i videregående skole, ikke privatister, og befant seg i en norsk hverdagskontekst.

Sentrale spørsmål i undersøkelsen er:

- Når og i hvilke sammenhenger er elevene i kontakt med spansk utenom skolen?

Og, hva kjennetegner denne kontakten? 
- I hvor stor grad benytter elevene seg av de økte læringsmulighetene og hvordan påvirkes språklæringsprosessen av dette?

- Hvilken plass har spansk i livene deres i et nåtid- og framtidsperspektiv?

Resultatene fra undersøkelsen presenteres og diskuteres i lys av et sosiokulturelt perspektiv på læring, og målet vårt er å få mer konkret kunnskap om hvordan elevenes deltakelse i ulike typer læringsrom arter seg i praksis og hvilken relevans spansk har for dem, altså hvor og når de opplever det som meningsfullt å kunne spansk. Vi tenker at økt kunnskap om elevenes kontakt med spansk kan gi oss bedre innsikt i hvordan de tar til seg erfaringer med språket og hvor de er på vei språklig.

\section{Bakgrunn}

Bakgrunnen for undersøkelsen er vår interesse for hvordan de siste års endringer i læringsvilkår og den handlingsorienterte tilnærminga som vi ser i lareplanen, påvirker elevenes språklæring, også utenom skolekonteksten, og da særlig hvilken betydning de kulturelle og kontekstuelle endringene har for elever med flere års formell opplæring i spansk. Det er ikke i Norge gjort noen forskning på elever som velger å fordype seg i spansk i vg3 og hvilke læringsrom de deltar i utenom skoletid.

I følge lareplanen er formålet med faget blant annet å gi eleven kulturell innsikt og styrke språkferdighetene: «Å lære et fremmedspråk dreier seg først og fremst om å bruke språket - å lese, lytte, snakke og skrive - i forskjellige sammenhenger.»

(Utdanningsdirektoratet 2006: 2). Dette bygger i stor grad på språk og læringssynet som forfektes i Det felles europeiske rammeverket for språk (Utdanningsdirektoratet 2011), heretter kalt rammeverket. En sentral tanke i rammeverket er at språkbrukere er sosiale aktører som utfører oppgaver i bestemte kontekster og det er i disse sammenhengene de får sin fulle mening (ibid: 10).

I et globalt perspektiv befinner spansk seg blant de fem mest talte språk i verden. Det er det tredje mest brukte språket på internett, og kommer på andre plass, etter engelsk, på Facebook. Spansk er det nest største språket på Wikipedia når det gjelder antall besøkende (Instituto Cervantes 2015: 24; 29-33). Av de europeiske språkene er spansk i størst vekst, og i store områder av verden benyttes det som lingua franca (Moreno Fernández 2015: 262-263; Moreno Fernández \& Otero Roth 2007: 28). Globalisering og teknologisk utvikling gjør at Norge stadig blir mer mangfoldig språklig og kulturelt, og spansk er en del av dette mangfoldet. Spansk er generelt sett mer nærværende i nordmenns liv og i det norske samfunnet enn bare for noen tiår tilbake: Antall spanskspråklige bosatt i Norge og antall nordmenn som foretar reiser til, eller som er bosatt i spanskspråklige land, har $\varnothing \mathrm{kt} .{ }^{i}$ Samtidig er samarbeidet med spanskspråklige land i forskningsøyemed og annen politisk, økonomisk og kulturell øyemed omfattende ${ }^{\text {ii }}$.

Også i formalisert utdanning er endringene merkbare: Antall spanskelever og studenter på verdensbasis er i vekst og teller i dag omlag 21 millioner (Instituto Cervantes 2015: 9). I Norge viser tallene en liknende tendens: Spansk har vært det mest valgte fremmedspråket på ungdomstrinnet og i videregående opplæring siden innføringa av Kunnskapsl $\varnothing$ ftet i 2006 (Utdanningsdirektoratet 2015: 54; Fremmedspråksenteret 2015a: 8). Skoleåret 2014/15 var det eksempelvis 19861 elever som hadde spansk nivå II som fellesfag i vg2, mens 648 elever hadde spansk nivå III som programfag i vg3 (Fremmedspråksenteret 2015b: 1-2).

Sammenlignet med andre programfag i videregående skole er dette antallet relativt lavt, men i 
forhold til andre programfag i fremmedspråk er det høyt. I høyere utdanning har spansk vært et av de mest populære studiene blant fremmedspråkene de siste årene (Fremmedspråksenteret 2015c: 3).

\section{Teoretisk ramme}

I et sosiokulturelt syn på læring og utvikling benytter vi kulturelle redskaper (artefakter) for å forstå omverdenen og handle i den: Gjennom deltakelse i sosiale praksiser i ulike kontekster tar vi i bruk de fysiske, kognitive og kommunikative ressursene som kulturen til enhver tid stiller til disposisjon, og utnytter disse i egen læring (Säljö 2001: 21). Vygotsky betraktet språket som det viktigste medierende verktøyet. Han understreket at kunnskaper og erfaringer eksisterer først og blir synlige mellom mennesker, på et interpsykologisk plan, så $i$ mennesket, på et intrapsykolgisk plan (Vygotsky 1978: 57). Individets tenkning har dermed et sosialt opphav.

Læring skjer, ifølge sosiokulturelle tradisjoner, gjennom menneskelig aktivitet, i formalisert utdanning og i andre miljøer, der det å formidle kunnskap ikke nødvendigvis er det primære (Säljö 2016: 121). Hverdagslæring kjennetegnes av å være spontan og vilkårlig, mens det i formell opplæring skjer en systematisk kunnskapsoppbygging. Som barn tilegner vi oss spontane, dagligdagse begreper gjennom samspill med andre i hverdagsaktiviteter, mens skolegangen gir en innføring i vitenskapelige begreper, og slik drives den språklige tenkningen på et høyere plan (Vygotskij 2001: 171). Læring i og utenom det organiserte læringsrom virker således gjensidig forsterkende: Gjennom deltakelse i sosial praksis i hverdagen plukker vi opp nye kunnskaper, samtidig som kunnskaper vi har tilegnet oss i formalisert utdanning fester seg (Säljö 2016: 26).

Innen fremmedspråksdidaktikken har blant annet Lantolf \& Thorne (2006; 2011) og Swain, Kinnear \& Steinman (2010) framhevet samarbeid som vesentlig i språklæringsprosessen: I interaksjon med andre på målspråket fanger vi opp og imiterer språklige uttrykk. Det dreier seg imidlertid ikke om en ren imitasjon av språklige modeller, men en omforming av ord, begreper og språklige mønstre: «[i]t involves goal directed cognitive activity that can result in transformation of the original model.» (Lantolf $\&$ Thorne 2011: 207). Å tilegne seg kunnskaper og ferdigheter er en suksessiv tilvenning til å bruke et redskap eller utføre en handling. I språklæringsøyemed betyr dette at innlæreren trenger å møte og ta i bruk språket i mange ulike sammenhenger før hun behersker det. Det er nettopp i samspill med omgivelsene gjennom språket man utvikler sin språkkompetanse (Tornberg 2009: 76).

Dagens samfunnsmessige strukturer, med digitalisering og globalisering, endrer vår relasjon til omverdenen og vår interaksjon med andre mennesker. Dette har stor innvirkning på hva slags diskursive miljøer elever har tilgang til i språklæringsprosessen da de i økende grad selv kan ta personlige valg og oppsøke situasjoner som innebærer språklige utfordringer (Lantolf \& Thorne 2006: 67-68). Det er imidlertid ikke nok at læringsmulighetene er til stede, elevene må selv gripe dem, det vil si ta i bruk medierende verktøy for å få tilgang til språket (Swain et al. 2010: 2).

\section{Metode}

Funnene våre baserer seg på resultatene fra to undersøkelser gjennomført blant Spansk IIIelever: den første i form av en enkel kartleggingsundersøkelse våren 2015, den andre i form av en kvalitativ intervjuunders $\varnothing$ kelse våren 2016. Som nevnt innledningsvis ville vi unders $\varnothing$ ke 
i hvilke sammenhenger elever som befinner seg i en norsk skole- og hverdagskontekst, er i kontakt med spansk utenom skolen. Vi valgte informanter på nivå III fordi denne elevgruppa har hatt opplæring i spansk over lang tid, noe som danner utgangspunkt for å kunne gjøre seg en rekke erfaringer med språket. De fleste Spansk III-elever har hatt spansk som fellesfag på nivå I og II i fem skoleår, fra 8. trinn til vg2, og har selv tatt et aktivt valg om å fordype seg i faget i vg $3{ }^{\text {iii }}$. De har følgelig språkkompetanse til å operere på et relativt høyt nivå i ulike kontekster der spansk brukes, og vi antok derfor at de ville kunne gi oss et bilde av deres kontakt med og bruk av spansk.

\section{Kartleggingsundersøkelsen skoleåret 2014/2015}

Gjennom kartleggingsundersøkelsen ville vi skaffe oss et bilde av elevgruppa: hvorfor de hadde valgt Spansk III, omfanget av kontakten deres med spansk i ulike læringsrom utenom skolen og hvilken plass de selv trodde spansk ville ha i livene deres i framtida. Hensikten var først og fremst å avdekke noen sentrale tendenser når det gjaldt graden av nærvær av spansk i informantenes livskontekst, $i$ et nåtidig og tenkt framtidig perspektiv, og slik identifisere enkeltområder vi kunne gå mer i dybden på i en oppfølgende kvalitativ intervjuundersøkelse.

Vi utarbeidet en elektronisk undersøkelse som skulle besvares anonymt, da geografi og skoletilhørighet ikke var noe vi ønsket å studere. Tanken var at dette ville gjøre det enkelt å delta og gi trygghet til å svare ærlig. I tillegg var det snakk om relativt få elever på landsbasis, og vi ville derfor unngå at deltakerne kunne identifiseres. Vi gjennomførte undersøkelsen langt ut i skoleåret da vi ville at elevene skulle ha vært gjennom store deler av Spansk III før de besvarte den.

Undersøkelsen var en blanding av åpne og lukkede spørsmål, og innholdsmessig delte vi den i to: Bakgrunnsinformasjon og spansk i hverdagen/fritida. Som bakgrunnsinformasjon ba vi informantene om å vurdere på en tredelt skala (ikke viktig / ganske viktig / veldig viktig) seks forhåndsdefinerte grunner for hvorfor de hadde valgt Spansk III (god karakter i spansk i vg2; venner; kulturelle interesser; bli god i språket; spansktalende familie; tilleggspoeng ved opptak til høyere utdanning). Vi spurte dem så om de hadde vært i ett eller flere spansktalende land, og de som hadde oppholdt seg lengre enn tre måneder sammenhengende, kunne spesifisere hvorfor. I tillegg skulle alle vurdere på en tredelt skala (ikke interessert / ganske interessert / veldig interessert) hvor opptatte de var av fem forhåndsdefinerte aspekter ved spanskfaget (de praktiske språkferdighetene; grammatikk; litteratur; musikk og/eller film; geografi, samfunn og/eller historie).

I den andre delen stilte vi spørsmål i tilknytning til spesifikke læringsrom som vi tenkte det var naturlig for elevene å være i kontakt med i hverdagen/fritida. Informantene skulle først krysse av for om de kjenner noen med spansk som morsmål og angi cirka antall. I en åpen rubrikk kunne de kort fortelle om de pleide å snakke spansk med dem. Deretter fikk de spørsmål om de noen gang hadde skrevet spansk uten at det hadde med skolearbeid å gjøre, og i så fall til hvem og hvorfor, samt om de i fritida oppsøker spansk på internett og i sosiale medier. Vi stilte et åpent spørsmål om hvor og når de sist hadde hørt spansk og ba dem angi i hvilke sammenhenger de trodde at de kom til å bruke spansk i framtida. Til slutt ba vi dem om å skrive hvilket yrke de trodde de ville ende opp med.

Å nå fram til informantene viste seg å være utfordrende: Få skoler tilbyr Spansk III i form av kun klasseromsundervisning på lokal skole, men flere steder i landet fins det fleksible og/eller nettbaserte tilbud for elever fra flere skoler samtidig. På innsamlingstidspunktet hadde vi ingen oversikt tilgjengelig over hvilke skoler som tilbød Spansk III og antallet elever 
ved disse. Målet var å spørre flest mulig elever om å delta, og vi sendte e-poster til skoler som hadde hatt Spansk III-grupper tidligere, lærere vi visste underviste på dette nivået, Fremmedspråksenteret og Utdanningsdirektoratet, der vi etterspurte navn på kontaktpersoner for Spansk III (lærere, fagkoordinatorer ved lokal skole, koordinatorer/hovedansvarlige for nettbasert undervisning). Vi søkte også etter aktuelle lærere på et lukket facebookforum for spansklærere. Resultatet etter disse henvendelsene var navn på 20 lærere som var involvert i Spansk III-undervisning, og vi sendte dem en e-post med direktelenke til unders $\varnothing$ kelsen og med oppfordring om å spørre sine elever om å delta.

Tretten av lærerne svarte oss raskt og positivt, og gjennomførte undersøkelsen blant elevene sine i perioden 06.04.15. - 18.05.15, mens sju lærere aldri svarte, selv etter to purringer. Vi hadde ingen oversikt over hvor mange elever hver av disse lærerne hadde og hvor mange som faktisk fikk tilbud om å delta i undersøkelsen og gjennomførte. Vi fikk inn i alt 181 svar. I etterkant ser vi at vi burde ha foretatt den noe tidligere i skoleåret da tidspunktet ble veldig nærme sluttvurdering i faget, noe som kan ha bidratt til lavere deltakelse. I ettertid fikk vi vite at 648 elever hadde valgt Spansk III skoleåret 14/15 (Fremmedspråksenteret, 2015b). Dette betyr at 181 svar utgjør $28 \%$ av det totale antall elever i faget, et lavere tall enn det vi hadde sett for oss. Vi ba om en tilbakemelding fra lærerne som gjennomførte undersøkelsen med sine elever på at de hadde gjort det, men vi vet ikke hvor mange av de aktuelle elevene som faktisk besvarte undersøkelsen. Allikevel mener vi at informantene er mange nok til å kunne skissere noen sentrale tendenser.

\section{Utdypende intervjuundersøkelse skoleåret 2015/2016}

Vi gjennomførte en oppfølgende kvalitativ intervjuundersøkelse blant neste års Spansk IIIelever (skoleåret 15/16), der vi gikk dypere inn på noen av tendensene vi hadde avdekket i kartleggingsundersøkelsen, med særlig henblikk på elevenes erfaringer med spansk i det nettbaserte læringsrommet, i nærmiljøet og i utlandet. Gjennom intervjuene håpet vi å få mer nyansert kunnskap om informantenes rolle som aktør i de ulike læringsrommene og hvilken betydning spansk har i livene deres. Vi oppfordret elevene til å fortelle om ulike situasjoner hvor de er i kontakt med spansk, og hva slags innhold denne kontakten har, for å få tydeligere fram i hvilke sammenhenger spansk oppleves som relevant for dem. Vi var i tillegg opptatt av hvorvidt og på hvilke måter informantene selv mente de klarte å iverksette og videreutvikle sin kompetanse i spansk i nye og konkrete situasjoner og om de så en kobling mellom det spanske språket og eget liv.

Vi lagde en intervjuguide med ti åpne spørsmål ${ }^{\text {iv }}$ som omhandlet hvorfor de hadde valgt Spansk III, hvor de hadde hørt spansk sist, hva de gjorde for å få tilgang til språket, og hvordan de trodde de kom til å bruke spansk i framtida. For å få et mer konkret innblikk i deres kontakt med spansk i det nettbaserte læringsrommet, ba vi dem gi eksempler fra egen hverdag og utdype disse. Videre ba vi dem reflektere over hvordan bruk av spansk i og utenom skolen kan påvirke språklæringa, for å se om det var noen registrerbare broer mellom skole og fritid.

Vi ville intervjue elever både fra Oslo og noen mindre plasser for å få variasjon i geografisk beliggenhet og størrelse på hjemsted. Denne gangen kontaktet vi lærere vi kjenner og ba dem spørre noen av sine elever om å delta. Vi endte opp med 24 elever fordelt på fire fylker, deriblant én stor og to mindre byer, i tillegg til Oslo. Vi la opp til semistrukturerte fokusgruppeintervjuer på to til fire elever, da reflekterende felleskap kan bidra til å starte en tankeprosess hos den enkelte (Jacobsen 2015: 160). Intervjuene ble gjennomført i perioden 
02.02.16.- 04.05.16, noen i fysisk møte, andre virtuelt via Skype. Informantene ble på forhånd informert om at det ble gjort lydopptak. Vi intervjuet hvert par/gruppe én gang i cirka 30-60 minutter. Vi lot samtalen flyte relativt fritt deltakerne imellom og stilte oppfølgingsspørsmål når de kom inn på spesielt interessante temaer for undersøkelsen. I etterkant transkriberte vi intervjuene. I transkripsjonen utelot vi fyllord og gjentakelser, mens vi forsøkte å ivareta hovedinnholdet

I analysen av det innhentede materialet tok vi utgangspunkt i tre hoveddimensjoner/kategorier vi hadde kommet fram til gjennom kartleggingsunders $\varnothing$ kelsen: årsakene til programfagvalget, elevenes tilgang til spansk i hverdagen/fritida og hvordan spansk inngikk i deres framtidsplaner. Vi leste først raskt igjennom transkripsjonen av alle intervjuene, og lagde så underkategorier ved å knytte spesifikke nøkkelord til hver dimensjon. Nøkkelordene var delvis basert på ord og uttrykk som var sentrale i resultatene fra kartleggingsundersøkelsen, delvis på ord og uttrykk som vi i gjennomlesningen av transkripsjonene hadde lagt merke til ofte ble gjentatt eller fremhevet av intervjupersonene. I den første hovedkategorien (Programfagvalg) endte vi opp med følgende underkategorier: forbedret språkkompetanse, tilleggspoeng, verdensspråk, nyttig kommunikasjonsverktфy og sosialt liv. I den andre (Spansk i hverdagen/fritida) delte vi underkategoriene etter de kommunikative språkferdighetene: lytte, snakke, skrive, lese, som omtales i laereplanen. I tillegg opprettet vi en egen kategori med elevenes konkrete eksempler på hvordan de fikk tilgang til spansk gjennom massemedia og internett. For å sortere informasjonen i den tredje og siste kategorien (Spansk i framtida), skilte vi mellom elever som kunne tenke seg å studere spansk som språkfag og elever som hadde andre studieplaner. Vi skilte også mellom elever som klart så for seg at de ville bruke spansk i ferie/fritid, studier/arbeid og de som ikke hadde noen klare tanker om dette.

\section{Resultatene fra kartleggingsundersøkelsen}

Vi delte resultatene fra kartleggingsunders $\varnothing$ kelsen inn i tre hovedkategorier: 1) Programfagvalget og faglige interesser, 2) Spansk i hverdagen/fritida, og 3) Spansk i framtida. Da ikke alle informantene besvarte alle spørsmålene, vil vi gjengi antallet i tillegg til prosentandelene der det er nødvendig i presentasjonen av resultatene.

\section{Programfagvalget og faglige interesser}

Ønsket om å bli god i språket oppgis som hovedgrunnen til å velge Spansk III (83 \% svarte veldig viktig). Nesten halvparten synes også at det er veldig viktig at de har fătt en god karakter i vg2 og at faget gir tilleggspoeng. En tredjedel svarer at den kulturelle delen er en veldig viktig årsak til å fordype seg i spansk. For $10 \%$ er spansktalende familiebakgrunn en ganske eller veldig viktig grunn. Det vil si at de aller fleste av informantene har en ikkespanskspråklig familiebakgrunn.

Når det gjelder graden av faglige interesser i det inneværende skoleåret i Spansk III skiller de praktiske språkferdighetene seg ut, hvor hele $97 \%$ svarer ganske eller veldig interessert, mens litteratur ligger i motsatt ende av skalaen, hvor $37 \%$ sier ikke interessert. Grammatikk, musikk og/eller film og geografi, samfunn og/eller historie har hovedtyngden av svarene på ganske interessert.

\section{Spansk i hverdagen/fritida}


Så godt som alle informantene har vært i et spansktalende land, kun $2 \%$ har ikke vært det. De fleste har vært i Spania. Bare to elever har kun vært i Latin-Amerika, mens $28 \%$ har vært både i Spania og Latin-Amerika. 21 informanter hadde oppholdt seg i et spansktalende land sammenhengende i over tre måneder, og av dem oppga 17 at de hadde vært utvekslingselever mens fire hadde bodd der med familien sin. Det betyr at de aller fleste av informantene har vokst opp utenfor målspråkområdet. En grunn til at nesten alle har svart at de har vært i et spansktalende land kan være at mange spanskklasser reiser på skoletur til Spania, men det forklarer ikke andelen som har vært i Latin-Amerika.

I forhold til muligheter til å kommunisere med morsmålstalere i egen

bekjentskapskrets oppgir $69 \%$ at de kjenner folk med spansk som morsmål, $35 \%$ av disse mer enn fem personer. $19 \%$ svarer at de kjenner spansktalende, men at de snakker norsk med disse. Få informanter fortalte nærmere om hvem de pleide å kommunisere med på spansk. De som svarte nevnte stort sett venner.

På spørsmålet om når og hvor de sist hørte spansk utenom undervisninga, fikk vi få opplysninger om tidspunktet, men de som oppgir det, svarer at det er kort tid siden (i et tidsspenn fra for cirka tre måneder siden til $i$ dag). Den største gruppa, på $36 \%$, svarte at de sist hørte spansk i nærmiljøet: på bussen, butikken, gata, jobben, treningsstudioet og liknende. Den nest største gruppa, 32 \%, hørte sist spansk på TV, radio, film eller internett, mens 27 \% oppgir i Spania eller andre land.

$70 \%$ av informantene oppgir at de en eller annen gang har skrevet spansk uten at det har med skolearbeid å gjøre, og de skriver først og fremst med venner. Andre ting som nevnes er familie, folk man har blitt kjent med på nettet, gjennom dataspill, i forbindelse med jobb, ferie eller alene for å øve eller for gøy. Som en av informantene skriver: Selv om det ikke har vart skolearbeid, går det mye på interesse for å bli bedre $i$ språket.

$61 \%$ av informantene sier at de oppsøker spanskspråklige sider på internett; $43 \%$ av disse sjelden, mens $18 \%$ gjør det ofte. Det vil si at $39 \%$ ikke oppsøker spansktalende sider på Internett utenom skolearbeidet. De fleste sier at de oppsøker nyheter eller fakta, mens musikk kommer på andreplass. Videre er det flere som nevner radio/TV/film, sport, blogger, sosiale medier og læringssider. $63 \%$ bekrefter at de bruker spansk i sosiale medier; $47 \%$ av og til, 16 $\%$ ofte, mens $37 \%$ sier nei.

\section{Spansk i framtida}

$53 \%$ av informantene tror at de kommer til å bruke spansk i både jobb/studier og ferie/fritid, $39 \%$ i bare ferie og/eller fritid og $5 \%$ i bare jobb-/studiesammenheng. Kun $2 \%$ tror ikke at de kommer til å bruke spansk i framtida.

$77 \%$ kan tenke seg å studere i et spansktalende områder uten å ha klare planer om det, $10 \%$ har konkrete planer, mens $13 \%$ ser på dette som uaktuelt. Når det kommer til å vurdere hvorvidt de kunne tenke seg å studere spansk som fag ved et norsk universitet/høgskole, kunne omtrent halvparten, $47 \%$, ikke tenke seg det. $30 \%$ syns det høres ut som en god idé, men har ingen konkrete planer, mens $13 \%$ ser for seg å studere spansk som del av et annet studium. Kun $7 \%$ kunne tenke seg å studere spansk som språkfag, mens bare $3 \%$ ser for seg en framtid som spansklærer.

Mange av informantene var usikre på framtidig yrkesvalg, men de som svarer ser for seg å ende opp med et prestisjetungt profesjonsyrke som lege, advokat, ingeniør, økonom eller psykolog. 


\section{Resultater fra den kvalitative undersøkelsen}

\section{Programfagvalget}

Så å si alle uttrykte at de valgte Spansk III fordi de hadde et reelt ønske om å bli bedre $i$ språket, særlig muntlig. Den store investeringen de hadde gjort i faget hittil var et avgjørende argument for å fortsette, og følgende elevsitat er karakteristisk: Det ville ha vart synd å bruke så mye tid på spansk og så glemme det igjen. Vel halvparten av de 24 informantene mente at tilleggspoeng ved opptak til høyere utdanning var en medvirkende faktor, men ikke hovedgrunnen. Et titalls informanter trakk fram det faktum at spansk er et verdensspråk uten at vi stilte dem direkte spørsmål om spansk som lingua franca. Dette utsagnet viser bevissthet om det spanske språkets utbredelse: Det er nyttig å kunne spansk, for det snakkes av mange, av hundre millioner. I USA, for eksempel, er det sinnssykt mange som snakker spansk. Søken etter større faglig fellesskap og opplevd mestring i møte med autentisk språk oppgis hyppig som årsaker: Jeg begynte å like spansk $i$ vg2 etter at vi hadde vart på skoletur i Spania. Der opplevde jeg at jeg forstod mye mer, at jeg virkelig hadde bruk for spansk. En annen hovedtendens i svarene er en generell interesse for å lære språk og beskrivelser som $g \phi y$, spennende, estetisk, praktisk, nyttig er gjennomgående når informantene skal forklare hvorfor de valgte å fordype seg i spansk.

\section{Spansk i hverdagen/fritida}

$\mathrm{Ni}$ av informantene oppgir at de hører spansk i nærmiljøet relativt ofte, mens noen aldri gjør det. Her peker informantene fra Oslo seg klart ut; de forteller utførlig om nylige episoder på gata, trikken, bussen og butikken, der de har hørt mennesker samtale på spansk. De reagerer da med å spisse $\varnothing$ rene for å teste om de forstår noe av det som blir sagt.

Felles for alle informantene er at de lytter til spanskspråklig musikk i fritiden, men hvor ofte og når varierer, fra av og til, hver dag, senest $i$ går kveld, $i$ dusjen, når jeg kjører bil, på fest med venner til kun før vi skal ha prфver. De lytter til spanskspråklig musikk både fordi de syns det er vakkert og fordi det er morsomt å forstå tekstene. I samtalene om hva slags musikk de hører på, kommer det fram at de ofte blir inspirert av en sang de har hørt på i en undervisningstime og at de deretter søker den opp på YouTube eller andre digitale musikktjenester. Så hører de på flere sanger som anbefales ut fra søket. I den forbindelse kommer informantene selv inn på spillelister de har med artister som Juanes, Shakira, Enrique Iglesias og generelt latinopop.

Informantene støter ofte på spansk tilfeldig på internett og i massemedia, for eksempel nevner flere at de hører spansk i dialoger i (nord-)amerikanske filmer: Det er masse spansk $i$ amerikanske filmer som vi liksom ikke skal forstå, og så forstår vi det. Det er kult. I den forbindelse påpeker de fordelen av å kunne trekke veksler både på sine engelsk- og spanskkunnskaper. Når det popper opp spansk i innlegg eller kommentarer på Facebook, YouTube og liknende, forsøker de å forstå hva som står, men skriver sjelden eller aldri innlegg på spansk selv. De understreker imidlertid at internettspråk ikke alltid er god spansk. Det er mye slang $i$ sosiale medier, på snap, insta og Facebook.

Informantene beskriver hvordan de mer og mindre bevisst oppsøker spanskspråklig musikk, film, radio og/eller TV med det for øyet å styrke sine lytte- og leseferdigheter og utvide ordforrådet. Noen forteller at de bruker TV-mediet systematisk for å få økt tilgang til språket, som denne: Jeg pleier å ta opp programmer fra RTVE Internacional, jeg følger med på et program som heter La moda og noen såpeoperaer. Jeg hører lite spansk til vanlig, og 
derfor tar jeg opp programmene. Et mindretall følger jevnlig med på spanskspråklige nyheter, blogger og «vlogs» (videoblogger). De fremhever fordelen med at [j] eg kan lytte flere ganger. $O g$ ta det saktere. Flertallet leser aldri spanskspråklig litteratur utenom skolearbeidet, men fem har fors $ø \mathrm{kt}$ å lese bøker, som for eksempel ungdomsromanen La ciudad de las bestias av Isabel Allende og en faktabok om den innfødte befolkningen i Sør-Amerika. Til tross for at de synes det er vanskelig, har de som mål å kunne lese spanskspråklige bøker i framtida.

Når det gjelder deltakelse i samhandling på spansk, refererer informantene mest til muntlig interaksjon i fysiske møter, mens chatting i sosiale medier også nevnes, men ikke i like stor grad. I eksemplene de gir, er bevisstheten om spansk som verdensspråk fremtredende, da alle, på en eller annen måte, har opplevd å benytte spansk som fellesspråk i konkrete kommunikasjonssituasjoner, som denne informanten: Vi var på restaurant $i$ Amsterdam i påskeferien, og de ved siden av var spansktalende. Jeg begynte å prate med dem. De var chilenere og syntes det var rart at jeg som var norsk kunne spansk. Vi pratet en god del og jeg fortalte om Norge. Omtrent halvparten reiser til Spania relativt hyppig med familie eller venner. Der praktiserer de spansk mest i butikker, på kafeer og restauranter, særlig når de befinner seg utenom store byer og turistområder. Opplevelser på skoleturer i forbindelse med spanskundervisninga trekkes hyppigst fram når de skal fortelle om egen deltakelse $\mathrm{i}$ autentiske kommunikasjonssituasjoner: På kvelden gikk vi ut og da ble vi kjent med noen spanske ungdommer, vi snakket spansk med dem hele tiden og brukte bare litt engelsk som stфtte.

To av informantene er i nær familie med spansktalende, men har ikke spansk som morsmål. Flere nevner imidlertid at de har spansktalende venner eller perifere spansktalende bekjente eller slektninger. Noen kommuniserer alltid på spansk med disse, mens de fleste kun lytter og prøver å få med innholdet i samtalene de er vitner til. I det store og hele tar informantene også med seg deler av det spanske språket inn i egen hverdag i kommunikasjon med klassekamerater og venner, både når de møtes fysisk og i sosiale medier: Vi tuller litt på spansk oss imellom, sier for eksempel «¿Qué pasa?» og Når vi chatter på Facebook om lekser og sånn, bruker vi av og til spanske ord og uttrykk. To av informantene har allerede benyttet spansk i deltidsjobber ved siden av skolen, i butikk og på treningsstudio: En av de som trente der var fra Costa Rica. Vi vekslet på å prate norsk og spansk for at begge skulle få språktrening.

\section{Spansk i framtida}

Ingen av informantene har konkrete planer om å studere spansk som språkfag, men tre kunne tenke seg det. Seks har klart for seg at de i framtidige studier $\emptyset$ nsker utveksling til den spansktalende verden, en av dem sier Jeg har søkt fag på UiO, eller så skal jeg begynne på American College of Norway, de har utveksling til California, der er det mye spansk, mens en annen har planlagt utveksling til Granada i sjuende semester i forbindelse med tannlegestudier. En generell tendens er at informantene anser spansk som relevant $\mathrm{i}$ studiesammenheng selv om de planlegger å studere andre fag, som økonomi: Spansk kommer til å bli veldig relevant $i$ business, fordi, etter hvert, kommer majoriteten til å snakke spansk. Tysk er viktig i Norge nå, men i framtida blir spansk mye viktigere internasjonalt.

Flertallet mener de vil ha bruk for spansk i framtida, ikke bare i ferie og fritid, men også i studier og arbeid, særlig med tanke på å knytte kontakter, både faglig og sosialt. De vektlegger at det er et fortrinn å ha kompetanse i spansk, ikke bare for å kunne kommunisere i spansktalende land, men også for å få innpass i spanskspråklige miljøer i Norge og i andre 
deler av verden: Det kan vare greit å ha muligheten til å snakke med flere folk og I utlandet blir de positivt overrasket når jeg snakker spansk, det gir litt status der, er omkvedet.

\section{Diskusjon}

Både kartleggings- og intervjuunders $\varnothing$ kelsen viser at mange av informantene er i kontakt med og bruker spansk i hverdagen og fritida, gjennom fysiske møter, massemedia, filmer, bøker og nettbaserte tjenester. Allikevel fant vi i kartleggingsundersøkelsen at $39 \%$ ikke oppsøker spansktalende sider på internett utenom skolearbeidet, og tendensen er den samme når det gjelder bruk av spansk i sosiale medier. I intervjuunders $\varnothing$ kelsen beskriver imidlertid flere hvordan de bevisst bruker nettbaserte og digitale verktøy for å få tilgang til språket. De bruker internett som medierende verktøy særlig for å styrke egne reseptive ferdigheter. Dette kan muligens forklares med at lytte- og lesekilder på nett er lett tilgjengelige; elevene kan oppsøke dem når det måtte passe og de er ikke avhengig av andre personer for å få til muntlig og/eller skriftlig interaksjon. Samtidig kan det å lytte til eller lese spansk alene gi rom til gradvis å bearbeide språklige inntrykk på det intrapsykologiske planet (Lantolf \& Thorne 2011: 207). Flesteparten av informantene i det kvalitative intervjuet kjenner noen som snakker spansk og oppsøker på egen hånd situasjoner der de kan anvende språket, ikke bare i spansktalende land, men også i Norge og andre land.

Når vi leser, skriver, lytter eller snakker på målspråket setter vi oss delmål på veien mot mer overordnede mål (Lantolf \& Thorne 2011: 218). I kartleggingsunders $\varnothing$ kelsen fant vi at det instrumentelle, altså et ønske om å bli bedre i språket, var den viktigste grunnen til å velge Spansk III, og at interessen for praktiske språkferdigheter var størst. Hovedtendensen i intervjuundersøkelsen var den samme: Informantene hadde som hovedmål å bli mer kompetente språkbrukere, særlig muntlig, dette for å oppnå gode karakterer i Spansk III, men ikke bare det: Å forbedre egne språkferdigheter inngikk i et langsiktig mål, nemlig å kunne anvende språket på et stadig mer avansert nivå i ulike livssfærer, både privat og i framtidig studie-/og arbeidsliv. Holdningen var at man fort, over hele verden, kan befinne seg i situasjoner der det å beherske spansk er et fortrinn eller påkrevd. En fellesnevner i eksemplene deres er at de velger å engasjere seg når de kommer opp i situasjoner der spansk brukes; de anstrenger seg for å forstå og gjøre seg forstått. Dette er i tråd med Swain, som understreker betydningen av å skape mening på målspråket sammen med andre (Swain et al. 2010: 43).

Kontakten med spansk er også av mer generell art: Flere oppsøker spanskspråklige nettsider for å holde seg informert og underholdes innen spesifikke interesseområder som mote, film og sport, hovedsakelig fordi disse, etter deres mening, er nyskapende og ofte først ute med siste nytt. Andre benytter spansk i sosiale medier for å opprettholde eller knytte nye sosiale bånd. Fordelen med det nettbaserte læringsrommet, ifølge informantene, er at det tillater dem selv å bestemme hvordan de vil møte målspråket, hva de skal lese og lytte til, hvem de skal kommunisere med og når, det vil si, det gir dem større kontroll over egen læringsprosess, de er aktører i egne liv, jamfør Lantolf \& Thorne (2006: 67-68).

I kartleggingsundersøkelsen svarte $36 \%$ at de sist hadde hørt spansk i nærmiljøet, og det er interessant at så mange nevner sin egen hverdag som et sted man hører spansk. I intervjuundersøkelsen registrerte vi samme tendens, særlig i Oslo, og dette er med på å forsterke elevenes opplevelse av at spanskfaget har relevans i eget hverdagsliv. Når de tilfeldigvis hører spansk, anstrenger de seg for å forstå. Det dreier seg altså om en viljestyrt 
oppmerksomhet, og det som kan fremstå som tilfeldig språklæring, er i realiteten en målrettet, meningsfull aktivitet, jamfør Lantolf \& Thorne (2011: 218).

Læring på tvers av skole og fritid fordrer at man kan ta i bruk sin kompetanse på en relevant måte i sammenhenger der det er aktuelt (Säljö 2016: 173). I løpet av samtalene kom informantene ofte selv inn på hvordan læring i og utenom skolen påvirker hverandre. Mange lar seg inspirere av temaer de har jobbet med på skolen, og vice versa, som denne informanten: Jeg har holdt muntlige presentasjoner om Juanes og har en lang spilleliste med sangene hans.. Skoleturer til Spania nevnes hyppig som en gyllen anledning til å kunne iverksette egen muntlig interaksjonskompetanse i autentiske situasjoner. Språklæringa blir dermed ikke bare en reproduksjon av kunnskaper, men får et performativt preg. Fritidsreiser til spansktalende eller andre land gir også mulighet til å iverksette spanskkompetansen, og informantene inntar da ofte rollen som ressurs for andre ved at de ordner opp på spansk. På denne måten opptrer elevene som sosiale aktører: De tar ansvar for at kommunikasjonen på spansk fungerer.

Kartleggingsunders $\varnothing$ kelsen viste større interesse for de praktiske språkferdighetene enn det kulturelle aspektet. Imidlertid kommer det mange kulturrelaterte interesser fram i de kvalitative intervjuene: Flere nevner spesifikke musikkartister, filmer, tv-serier og bøker de er opptatt av. En interessant tanke er at interessen for den praktiske siden av språket (det å kunne bruke det) utgjør en naturlig del av informantenes hverdag og at de inkluderer kulturelle uttrykksformer fra den spansktalende verden i denne.

Flesteparten i begge unders $\varnothing$ kelsene trodde de ville ende opp i et prestisjetungt yrke hvor spanskkunnskaper i regelen ikke er påkrevd. Intervjuunders $\varnothing$ kelsen viste imidlertid at dette ikke var ensbetydende med at de så for seg et framtidig studie- og yrkesliv uten spansk. Tvert imot inngikk spansk hos mange som en integrert del av framtidige studieplaner, eksempelvis gjennom et internasjonalt semester i et spansktalende land.

\section{Konklusjoner}

Begge undersøkelsene viser at informantene i varierende, men utstrakt grad benytter seg av de $\emptyset$ kte læringsmulighetene, og at spansk er en større eller mindre del av livene deres også utenom skolekonteksten. De møter språket i ulike sammenhenger og mener selv at dette er med på å drive språklæringsprosessen videre. Dette samsvarer med Tornberg (2009: 76), og det kan se ut som fokus på praktisk tilnærming i spanskundervisninga (jamfør laereplan og rammeverket) kombinert med elevenes praktiske bruk av språket i hverdag og fritid hverandre gjensidig forsterker hverandre. Funnene våre gir kun noen indikasjoner på i hvilken retning interesserte spanskelever utvikler seg: De er bevisste på at kontakt med spansk utenom skolen er med på å prege språklæringa og vet å utnytte de nye læringsvilkårene for å videreutvikle sin kompetanse, særlig gjennom digitale medier, men også i sitt eget nærmiljø og under opphold i spanskspråklige områder. De viser evne til å reflektere rundt bruk av formell og uformell stil i ulike kontekster.

Informantene opplever det som meningsfullt å engasjere seg i møte med språket. De er i stand til å opptre som aktører i den forstand at de bruker sin individuelle kompetanse strategisk for å oppnå både del- og overordnede mål i språklæringa. Mange har personlig erfart at spansk gir dem en unik mulighet til å stifte nye bekjentskaper og at det er et effektivt kommunikasjonsverktøy i situasjoner der spansk benyttes som fellesspråk. Denne troen på at spansk vil komme dem til nytte i framtida er sosialt konstruert, resultat av de ulike sosiokulturelle kontekstene de har deltatt i tidligere, jamfør Swain et al. (2010: 11). 
Interaksjon med omverdenen har vist dem at spansk er et verdensspråk: Man kan dra nesten hvor som helst og bruke det. Kanskje forteller dette oss at spansk er i ferd med å få større gjenklang hos norske elever, slik som engelsk lenge har hatt. Det bør forskes videre på hvordan denne elevgruppas innsikt og bevisste tilnærming til spansk kan utnyttes i flere sammenhenger og på lavere trinn.

\section{Litteratur}

Fremmedspråksenteret (2015a). Elevenes valg av fremmedspråk på ungdomstrinnet. En analyse av utviklingen siden innføringen av Kunnskapsløftet. Notat 1/2015. Hentet 15.07.16. fra

http://www.fremmedspraksenteret.no/neted/services/file/?hash=64d2ac4ff4e74e 766fd9f08 $67977 \mathrm{c} 608$

Fremmedspråkssenteret. (2015b). Engelsk og fremmedspråk i videregående opplæring 2014-2015: stabil situasjon for språkfagene. Notat 2/2015. Hentet 15.07.16. fra http://www.fremmedspraksenteret.no/neted/services/file/?hash=d50c3ee366d277fce14c2e $140 \mathrm{e} 1 \mathrm{a} 82 \mathrm{~d} 8$

Fremmedspråksenteret. (2015c). Samordna opptak 2015: Spansk og tysk fortsetter å $\varnothing$ ke, fransk og mindre underviste språk går ned. Notat 4/2015. Hentet 15.07.16. fra http://www.fremmedspraksenteret.no/neted/services/file/?hash=4b00a0a06294db6647a32 715 cbea4907

Instituto Cervantes (2015). El español: una lengua viva. Informe 2015. Instituto Cervantes. Hentet fra http://elnuevosol.net/wp-content/uploads/2016/05/espanol_lengua-viva_20151.pdf

Jacobsen, D. I. (2015). Hvordan gjennomf $\phi r e ~ u n d e r s \phi k e l s e r . ~ I n n f \phi r i n g ~ i$ samfunnsvitenskapelig metode. Oslo: Cappelen Damm Akademisk.

Lantolf, J. P. \& S. L. Thorne (2006). Sociocultural Theory and the Genesis of Second Language Development. Oxford: Oxford University Press.

Lantolf, J. P. \& S.L. Thorne (2011). Sociocultural Theory and Second Language Learning. I: VanPatten, B. \& J. Williams (red.). Theories in Second Language Acquisition. New York: Routledge.

Moreno Fernández, F. (2015). La maravillosa historia del español. Barcelona: Espasa Libros.

Moreno Fernández F. \& J. Otero Roth (2007). Atlas de la lengua española en el mundo. Barcelona: Ariel.

Säljö, R. (2001). Laring i praksis. Et sosiokulturelt perspektiv. Oslo: Cappelen Akadmisk forlag.

Säljö, R. (2016). Laring. En introduksjon til perspektiver og metaforer. Oslo: Cappelen Damm Akademisk.

Swain, M., Kinnear P. \& L. Steinman (2010). Sociocultural Theory in Second Language Education: An Introduction through Narratives. Bristol: Multilingual Matters.

Tornberg, U. (2009). Språkdidaktik. Malmö: Gleerups Utbilding.

Utdanningsdirektoratet. (2006). Lareplan i fremmedspråk. Programfag i utdanningsprogram for studiespesialisering. Hentet 15.07.16. fra http://www.udir.no/k106/PSP1-01

Utdanningsdirektoratet. (2011). Det felles europeiske rammeverket for språk: lacing, undervisning, vurdering. Oslo: Utdanningsdirektoratet.

Utdanningsdirektoratet. (2015). Utdanningsspeilet. Oslo: Utdanningsdirektoratet. Hentet fra 
http://www.udir.no/globalassets/filer/tall-og

forskning/statistikk/uspeilet/utdanningsspeilet_2015.pdf

Vygotskij, L. S. (2001). Tenkning og tale. Oslo: Gyldendal Akademisk.

Vygotsky, L. S. (1978). Mind in Society: the Development of Higher Psychological processes.

Boston: Harvard University Press.

\footnotetext{
${ }^{\mathrm{i}}$ Vi har ikke noen pålitelige tall på dette, men vet at det er snakk om et $ø$ kende antall utvekslingsstudenter, arbeidstakere og turister, i tillegg til de spansktalende som bor her permanent. I 2008 besøkte ca. 800.000 nordmenn Spania (Hedemann 2008, s. 26), og i følge turistavdelingen ved Den Spanske Ambassaden har dette tallet $\varnothing \mathrm{kt}$ betraktelig de siste årene, med 1.430 .000 bes $\varnothing$ kende i 2015 .

${ }^{\text {ii }}$ Norge importerte varer fra Spania for nesten ti milliarder kroner og eksporterte varer til Spania for cirka femten milliarder kroner i 2014 (SSB). I tillegg kommer handel med Latin-Amerika, spansk i populærkulturen og andre kulturelle innslag.

iii For å få studiekompetanse må man ha gjennomført ett og samme fremmedspråk på nivå I og nivå II som fellesfag eller gjennomført ett fremmedspråk på nivå I på ungdomstrinnet og et annet fremmedspråk på nivå I (fellesfag) i videregående skole. Elevene kan i regelen velge mellom flere språk på nivå I og nivå II, avhengig av de forskjellige skolenes tilbud. På landsbasis er spansk er størst både på ungdomstrinnet og i videregående skole, og deretter kommer tysk og fransk.

iv Spørsmålene vi stilte i den kvalitative intervjuundersøkelsen:

1. Hvorfor har dere valgt Spansk III?

2. Hva liker dere av spanskspråklig kultur, for eksempel musikk, film, tv-serier, bøker?

3. Hvor kommer man i kontakt med spansk på stedet der du bor, i Norge?

4. Kjenner dere noen som har spansk som morsmål? Hvilket språk snakker dere med dem? Snakker disse personene spansk seg imellom?

5. Hvor og når hørte dere sist spansk utafor klasserommet?

6. Oppsøker dere spansk i fritida? Bruker dere spansk i sosiale media? Kan dere gi noen eksempler?

7. Har dere deltatt/pleier dere å delta i samtaler på spansk? Hvor? Hvordan? Hva snakker/skriver dere om?

8. Hva slags plass har spansk dere imellom? Er spansk språk eller kultur noe dere "holder på med" dere imellom?

9. Hvordan tror dere at dere kommer til å bruke spansk i framtida?

10. Kan dere si noe om hvordan bruk av spansk i og utenom skolen påvirker spansken deres?
} 